Article

\title{
Structuring of Dragonfly Communities (Insecta: Odonata) in Eastern Amazon: Effects of Environmental and Spatial Factors in Preserved and Altered Streams
}

\author{
José Max Barbosa Oliveira-Junior ${ }^{1,2, * \mathbb{C}}$ and Leandro Juen ${ }^{1}$ (i) \\ 1 Programa de Pós-Graduação em Zoologia, Programa de Pós-Graduação em Ecologia, Laboratório de \\ Ecologia e Conservação, Universidade Federal do Pará, Rua Augusto Correia, No 1, Bairro Guamá, \\ Belém 66075-110, Pará, Brazil; leandrojuen@gmail.com \\ 2 Instituto de Ciências e Tecnologia das Águas, Universidade Federal do Oeste do Pará, Rua Vera Paz, \\ s/n (Unidade Tapajós) Bairro Salé, Santarém 68040-255, Pará, Brazil \\ * Correspondence: jose.mbo@ufopa.edu.br; Tel.: +55-93-99196-8990
}

Received: 11 July 2019; Accepted: 29 August 2019; Published: 27 September 2019

check for updates

\begin{abstract}
The evaluation of the effects of environmental factors on natural communities has been one of the principal approaches in ecology; although, over the past decade, increasing importance has been given to spatial factors. In this context, we evaluated the relative importance of environmental and spatial factors for the structuring of the local odonate communities in preserved and altered streams. Adult Odonata were sampled in 98 streams in eastern Amazonia, Brazil. The physical features of each stream were evaluated and spatial variables were generated. Only environmental factors accounted for the variation in the Odonata community. The same pattern was observed in the suborder Zygoptera. For Anisoptera, environmental factors alone affect the variation in the community, considering all the environments together, and the altered areas on their own. As the two Odonata suborders presented distinct responses to environmental factors, this partitioning may contribute to an improvement in the precision of studies in biomonitoring. We thus suggest that studies would have a greater explanatory potential if additional variables are included, related to biotic interactions (e.g., competition). This will require further investigation on a finer scale of environmental variation to determine how the Odonata fauna of Amazonian streams behaves under this analytical perspective.
\end{abstract}

Keywords: Metacommunity; partitioning of variance; Anisoptera; Zygoptera; neutral theory; niche theory

\section{Introduction}

One of the primary objectives of ecological research has traditionally been the understanding of the factors that determine the distribution of species in natural environments [1]. The variation over time in the composition and abundance of species in a community provides an important parameter for the understanding of the processes that determine its structure [1]. Local and regional processes, such as biotic and abiotic factors, the climate, primary productivity, habitat type, and interspecific interactions, all have a profound effect on community structure [2].

More complex environments would be expected to have a higher species richness due to the greater diversity of ecological niches, related primarily to the availability of feeding resources and environmental conditions [3]. From this perspective, most ecological studies have focused on the environmental factors that determine community structure on a local scale [4]. Most of these studies 
are based on the assumption that the availability of niches will determine the composition and diversity of a community, i.e., niche theory [5]. In this case, the distribution of species will be determined by abiotic factors and the way in which different species, with distinct requirements in terms of conditions and resources, will partition the existing niches, so that the greater the environmental heterogeneity, the higher the rate of species substitutions, and the lower the similarity among sites [5].

There is a contrasting spatial approach (neutral theory), however, which assumes that all species have identical aptitudes [6] and thus the same probability of colonizing any given environment. In this case, the principal factor driving the similarity of communities at a regional level would be the limitations imposed on dispersal by the geographic distance between communities [6,7]. In this case, sites located more closely together will be more likely to be colonized by members of the same species found in neighboring communities and, consequently, to share more species [4]. Even in completely homogeneous environments, then, dissimilarities among communities will arise as a result of the spatial limitations imposed by the dispersal capacity of the different species [6,8].

While studies of the structuring of natural communities have tended to focus on the role of local environmental conditions, such as disturbances, competition, and abiotic conditions [9], in recent years, spatial processes (geographic distance) have gained growing importance in the analysis of the influence of these different factors $[10,11]$. Countless studies have attempted to describe or account for the influence of environmental processes and/or spatial factors on the structure of dragonfly communities in various parts of the world [12-18], although only a relatively small number have focused explicitly on the contributions of both factors in the context of a single system $[19,20]$. Four notable exceptions, all from Brazil, are Juen and De Marco [4], Brasil [21], and Alves-Martins [22] with studies of adult Odonata in Amazonian streams, and the study of Mendes et al. [23], who focused on larvae in streams in the Amazon-Cerrado transition zone.

Major environmental disturbances may modify environmental and/or spatial factors, leading to the elimination of the most sensitive local species, and alterations in the organization of the community [24]. A marked reduction in the environmental integrity of a body of water may lead to modifications of the natural dynamics of biological communities, resulting in the loss of aquatic biodiversity $[25,26]$. Alterations to habitat structure caused by deforestation in the drainage basin affect trophic dynamics and may alter Odonata species composition and diversity [14,27-33]. As the distribution of many organisms is related directly to the effects of impacts on the ecosystem [34], it is fundamentally important to understand the respective effects of environmental and/or spatial factors in preserved and altered environments.

The order Odonata is amongst the oldest of the winged insects [35]. Odonata individuals have a relatively long life cycle (when compared to mosquitoes and other Diptera [36]), up to a year in the tropics [37]. They are widely distributed in aquatic systems [15,38], and present a dual life cycle, where larvae are aquatic and adults are terrestrial/aerial [39]. The fact that Odonata larvae and adults occupy two different environments suggests that this group can provide valuable information on changes occurring in both aquatic and terrestrial environments [40,41].

In this context, we evaluated the relative importance of environmental and spatial factors in the structuring of the local communities of adult Odonata in both preserved streams and sites altered by farming and ranching activities in two regions of eastern Amazonia, which varied considerably in area and the integrity of the study streams [42]. Our operational hypothesis was that the structure of local communities is determined primarily by environmental factors, such as the structure of the riparian vegetation, human impacts, and physical-chemical variables, in both types of environment (preserved and altered). In this case, as demonstrated in a number of previous studies of aquatic macroinvertebrates [23,43-45], the communities will be structured according to the assumptions of niche theory, given the sensitivity and ecological requirements of the different Odonata species. Spatial factors should have little effect on community structure, especially considering the waterway connections and the respective dispersal capacities of the two Odonata suborders. 
We do not expect all individuals (e.g., suborders) to respond to these effects in a uniform manner. In the specific case of the Odonata, there is considerable variation in the dispersal capacity and ecological requirements of the two suborders, and even among members of the same suborder (see $[29,31,46]$ ). In this case, if the environment is the primary factor structuring the Odonata community, its effects would be observed more clearly in the species of the suborder Zygoptera, which have more restricted environmental requirements and reduced dispersal capacity, related primarily to their smaller body size [47].

\section{Materials and Methods}

\subsection{Study Areas}

The present study focused on two areas of eastern Amazonia, one in the municipality of Paragominas and the other in the municipalities of Santarém and Belterra, all in the Brazilian state of Pará (Figure 1). Paragominas (1.9 Mha) is located in northeastern Pará $\left(02^{\circ} 59^{\prime} 51^{\prime \prime} \mathrm{S}, 47^{\circ} 21^{\prime} 13^{\prime \prime} \mathrm{W}\right)$, with mean annual precipitation of $1766 \mathrm{~mm}$, mean annual temperature of $27^{\circ} \mathrm{C}$, and relative humidity of $81 \%$ [48]. With a total area of 1 Mha, Santarém $\left(02^{\circ} 26^{\prime} 22^{\prime \prime} S, 54^{\circ} 41^{\prime} 55^{\prime \prime} \mathrm{W}\right)$ and Belterra $\left(02^{\circ} 41^{\prime} 54^{\prime \prime} \mathrm{S}\right.$, $\left.54^{\circ} 53^{\prime} 18^{\prime \prime} \mathrm{W}\right)$ are located in the western extreme of the state, where mean annual precipitation is $1920 \mathrm{~mm}$, the mean annual temperature is $25^{\circ} \mathrm{C}$, and relative humidity is $86 \%$ [49]. The climate in Paragominas is predominantly of the $A f$ type in the Köppen classification system, while in Santarém and Belterra, types $A m$ and $A m w$ predominate (in both municipalities). These climate types correspond to tropical rainy climates with a short, well-defined dry season.

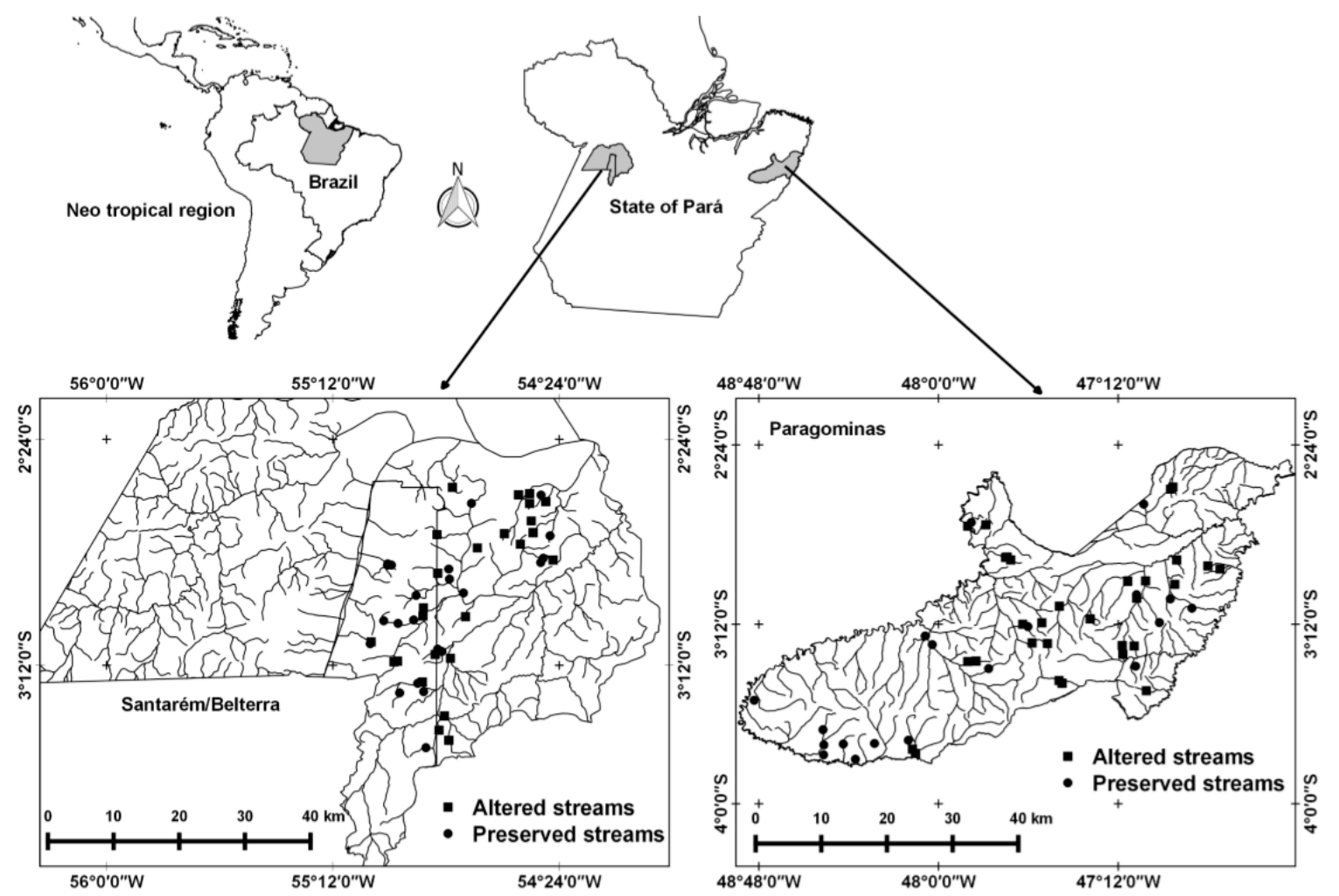

Figure 1. Drainage basins and streams sampled in the regions of Santarém/Belterra and Paragominas, in Brazilian Amazonia, Pará.

The vegetation of the Paragominas region is classified as dense rainforest [50], while tropical forest is the predominant vegetation type in Santarém and Belterra, with the exception of the Amazonian savannas found in the northeastern extreme of Santarém [51]. Both regions are characterized by a gradient of land use [52], with impacted areas including secondary forests, regrown after 
clear-cutting [53], plantations of trees, predominantly of eucalypt (Eucalyptus sp. L'Hér.), teak (Tectona grandis L.), and Brazilian firetree (Schizolobium parahyba var. amazonicum Huber ex Ducke), cattle pasture, and other crops, mainly rice and soybean (Oryza sativa L.; Glycine max L.) [31,42,52]. At the opposite extreme, large tracts of well-preserved, climax forest can still be found, with little evidence of logging [31,42,52]. In this context, the inclusion of the two regions in the study amplified both its environmental and spatial dimensions, given the potential for the expansion of the gradient examined.

\subsection{Data Collection}

\subsubsection{Biological Samples}

A total of 98 streams were sampled in the two regions during the dry season, of which 50 were surveyed in Paragominas between June and August 2011, and 48 in Santarém-Belterra, in July and August 2010. Data were collected during the dry season because the intensity of the precipitation during the rainy season creates logistic difficulties and interferes in the activity patterns of adult Odonata (see $[31,38,54,55]$ ). In addition, some studies [56,57] have shown that Odonata abundance and species richness tend to be higher during the dry season and sampling was restricted to these months to reduce 'noise' due to seasonal effects [58].

In each stream, a $150 \mathrm{~m}$ stretch was demarcated and subdivided into 10 sections of $15 \mathrm{~m}$, separated by margin-to-margin transects, which were denominated A (furthest downstream) through $\mathrm{K}$, furthest upstream [59,60]. The sampling consisted of the longitudinal $15 \mathrm{~m}$ sections subdivided into three segments of $5 \mathrm{~m}$, of which only the first two were sampled in each case, resulting in a final sample of 20 five-meter segments.

Temperature and relative humidity were measured in a shaded location adjacent to each stream (150 m stretch). Samples were collected invariably between 10:00 $\mathrm{h}$ and 14:00 $\mathrm{h}$, when the sun's rays reached the main stream channel. These minimum conditions were necessary to guarantee that all the different groups of Odonata (conformers, heliotherms and endotherms) were present at the moment of sample collection (see $[54,55,61])$. The adult specimens were collected using an entomological handnet (40 $\mathrm{cm} \varnothing, 65 \mathrm{~cm}$ deep, with an aluminum handle $90 \mathrm{~cm}$ long) following the protocol established by Ferreira-Peruquetti and De Marco [62] and Oliveira-Junior et al. [31]. The specimens were preserved following Lencioni's [63] protocol. Each stream was sampled by a single collector during 1 hour [31], with approximately 3 minutes in each segment. The distance between the sampling points guaranteed the independence of the samples [31].

The specimens were identified using taxonomic keys and specialized illustrated guides [63-70], as well as comparisons with the voucher material available in the collection of the Zoology Museum of the Federal University of Pará, Brazil. Once identified, the specimens were deposited as vouchers in the same collection.

\subsubsection{Environmental Predictors}

Nessimian et al. [71] developed the habitat integrity index (HII) to quantify the integrity of streams. This index is made up of 12 items that describe the environmental conditions found in the stream, through a visual evaluation of the following features: land use patterns adjacent to the riparian vegetation, the width of the riparian vegetation and its degree of preservation, the condition of the riparian forest with a radius of $10 \mathrm{~m}$ of the stream, the types of sediment found in the channel, and the presence of retention devices, the structure and erosion of the margins, the characteristics of the stream bed in terms of the substrate, aquatic vegetation, detritus, and distribution of areas of rapids, pools, and meanders. Each item is made up of four to six alternatives, which are ranked to evaluate the integrity of the system, ranging from 0 (least integrity) to 1 (most integrity). This index is related directly to the degree of conservation of the environment and has been applied successfully in a number of previous studies that have evaluated the integrity of aquatic systems $[14,29,31,72,73]$. 
Peck et al.'s [60] environmental assessment protocol, known as the Field Operations Manual for Wadeable Streams (FOMWS), and physical-chemical factors of the water were used to measure environmental predictors at each stream, in order to standardize the measurement of environmental conditions. This protocol uses a set of quantitative metrics of the physical habitat, such as the riparian vegetation, human impacts not related to the riparian vegetation, and features of the structure of the stream channel. For each category, the following predictor variables were used: (i) Riparian Vegetation: mean amount of canopy over the channel, canopy of large trees, herbaceous stratum, exposed soil, and mean total cover; (ii) Human Impact: proximity of buildings, roads, refuse dumps, plantations, forestry plantations, and total impact; (iii) Structure of the channel: humid width, height of the seasonal bed, angle of the margins, macrophytes, quantity of woody debris ( $>60 \mathrm{~cm}$ in diameter and $5 \mathrm{~m}$ in length) in the channel, hanging vegetation, immersion of the channel, slope, and sinuosity of the stretch of stream, depth and discharge. This protocol includes a set of environmental metrics (e.g., canopy opening, width, depth, and human impact) that have been shown to play an important role in the structuring of Odonata communities. All the metrics included in the protocol were calculated using the procedures described by Kaufmann et al. [59].

A Horiba ${ }^{\circledR}$ U-51 multiparameter probe was used to measure five physical and physical-chemical descriptors of the water: electrical conductivity $(\mu \mathrm{S} / \mathrm{cm}), \mathrm{pH}$, dissolved oxygen $(\mathrm{mg} / \mathrm{L})$, total dissolved solids, and water temperature $\left({ }^{\circ} \mathrm{C}\right)$.

\subsubsection{Spatial Predictors}

Spatial variables were generated using a Principal Coordinates of Neighboring Matrices (PCNM) approach [74]. The PCNM was based on a matrix of Euclidean distances among the sample sites, which was run through a principal coordinates analysis (PCoA), and the eigenvectors with positive eigenvalues were extracted for a posteriori analyses. These eigenvectors, normally known as spatial filters [75], were used as our spatial predictor variables, resulting in a final total of five spatial filters. The PCNM was executed in the SAM (spatial analysis in macroecology) program [76].

\subsection{Data Analysis}

To avoid problems of multicollinearity among the environmental variables [60] metrics and the physical and physical-chemical variables of the water, matrices of Pearson correlation coefficients were established. When a correlation of at least 0.70 was found between two variables, we selected the variable known to have a systematic influence on the occurrence of Odonata [77]. A forward stepwise procedure was used to select the environmental variables model (a set of 239 variables) which best explain the variation observed in the composition of the Odonata, anisopteran, and zygopteran communities.

To evaluate the distinction between the conservation categories of the streams, the values of the 12 items of the HII that describe the prevailing environmental conditions of the study streams were summarized in a principal components analysis (PCA). To determine which principal components should be retained for analysis, we used the randomness obtained by the broken-stick model [78]. To test whether the conservation categories (preserved and altered) were significantly different from one another, the scores generated by the PCA were tested using Student's $t$-test $(p<0.05)$. The variation of each conservation category was obtained by a multivariate permutation analysis of dispersal $\left(\right.$ PERMDISP $\left.=P_{\text {perm }}\right)$, based on the distance of each sample to the group mean [79].

A partial redundancy analysis, or pRDA [80], was used to evaluate the relative importance of environmental and spatial factors on the structure of the Odonata communities. Prior to this analysis, the density data were transformed using Hellinger's method [81], which is recommended for the preservation of the Euclidian distance among sample units in an $n$-dimensional space, as well as controlling for the problem of the lack of linearity in the raw abundance data [81,82]. The total variation explained by the pRDA is partitioned between the exclusive [a and b] and combined [c] contributions of the predictors [83]. In this case, the variation in community structure is divided into (i) "pure" environment [a], the portion accounted by environmental factors, without the influence of 
spatial factors, and (ii) "pure" space [b], the portion of the variation explained exclusively by spatial factors, independently of the environmental factors. The variation explained by a combination of environmental and spatial factors is represented in [c]. An additional, residual fraction [d] is not accounted for by either environmental or spatial factors [83]. This analysis was robust, even in the presence of the collinear variables in the tables of exploratory data, which did not need to be excluded for the tests [80,82].

All the analyses were run in the vegan and MASS packages [84,85] of the R program [86].

\section{Results}

\subsection{Description of the Odonata Communities}

A total of 3588 Odonata specimens were collected, representing nine families, 49 genera, and 134 species. Most (2415) of the specimens belonged to the suborder Zygoptera, distributed in six families (Calopterygidae, Coenagrionidae, Dicteriadidae, Megapodagrionidae, Perilestidae, and Polythoridae), 20 genera, and 71 species. The suborder Anisoptera was represented by 1173 specimens, belonging to three families (Aeshnidae, Gomphidae and Libellulidae), 29 genera, and 62 species.

In the Zygoptera, the Coenagrionidae was the most common family, with 1155 specimens, with species of the genus Argia being the most common $(n=438)$, followed by Epipleoneura $(n=351)$, and Neoneura ( $\mathrm{n}=92)$. In the case of the Anisoptera, the Libellulidae was the most abundant family, with 1154 specimens, and the genera Erythrodiplax $(\mathrm{n}=552)$, Oligoclada $(\mathrm{n}=167)$ and Diastatops $(\mathrm{n}=114)$ were the most common.

\subsection{Abiotic Characteristics of the Streams}

The principal variables that accounted for the distinction of the sample points were HII (which varied from 0.15 to 0.99$)$, electrical conductivity $(7.00-76.20 \mu \mathrm{S} / \mathrm{cm})$, mean canopy cover $(0.0-100.0 \%)$, buildings or infrastructure $(0.00-0.63 \%)$, total impact (mean of all impact: $0.00-2.73 \%$ ), discharge $\left(0.01-1.45 \mathrm{~m}^{3} / \mathrm{s}\right)$, and depth $(5.76-86.89 \mathrm{~cm})$. The association of the two PCS axes represented $46.56 \%$ of the environmental variation (model selected for the Odonata).

Based on the HII variation ( 0.15 to 0.99$)$, the 98 streams were classified in two arbitrary categories of conservation (Figure 2A): altered ( $\mathrm{HII}=0.15-0.69 ; 55$ streams) and preserved $(0.70-0.99 ; 43$ streams). The separation of the streams into two conservation categories was significant $(t=13.292 ; \mathrm{df}=96$; $p<0.001$ ) (Figure 2B).

The association of the two PCA axes represented $58.23 \%$ of the environmental variation. Only the first axis was analyzed, given that the second axis did not present an observed value greater than that estimated by the broken-stick procedure (which was adopted whenever a situation of this type arose). The first axis explained $45.04 \%$ of the results (eigenvalue $=5.40$ ). In this analysis, the samples were clearly separated by conservation category. The preserved streams had a positive relationship with environmental integrity, being grouped in the direction of the highest values for the width and degree of preservation of the riparian forest (Figure 2A). The altered streams were characterized by a significant loss and changes in the state of preservation of the riparian forest, with a group of these streams being associated negatively with the integrity of this vegetation (Table 1, Figure 2A).

It is important to note here that the variables that most contributed to the formation of the first axis are closely related to the physical structure of the riparian vegetation. These variables are associated negatively with the level of conservation of these environments, including the width of the riparian forest (WRF), degree of preservation of the riparian forest (DPRF), and the condition of the riparian forest within a radius of $10 \mathrm{~m}$ (CRF10) (Table 1, Figure 2A).

With regard to their dispersal in relation to the centroid of each group, the conservation categories varied significantly in environmental heterogeneity $\left(\mathrm{F}=16.134 ; P_{\text {perm }}=0.001\right)$. Altered streams 
were more heterogeneous than preserved ones, i.e., altered environments present a mean of 0.23 environmental variation, more than preserved environments.

Table 1. The 12 items of the habitat integrity index (HII) that describe the environmental conditions of the study streams sampled in two regions of Brazilian Amazonia in the state of Pará, and their correlations with axes 1 and 2 of the principal components analysis (PCA).

\begin{tabular}{llc}
\hline Variables of the Habitat Integrity & \multicolumn{2}{c}{ Loading } \\
\cline { 2 - 3 } Index (HII) & Axis 1 & Axis 2 \\
\hline $\begin{array}{l}\text { Pattern of land use in the area } \\
\text { outside the riparian vegetation }\end{array}$ & 0.028 & 0.087 \\
zone (PLUORV) & & \\
Width of the riparian forest (WRF) & $0.141 *$ & 0.033 \\
Degree of preservation of the & $0.133 *$ & 0.013 \\
riparian forest (DPRF) & & \\
Condition of the riparian forest & $0.133 *$ & 0.012 \\
within a radius of 10 m (CRF10) & 0.079 & 0.059 \\
Retention devices (RD) & 0.083 & 0.104 \\
Sediments in the channel (SC) & 0.038 & 0.231 \\
Structure of the river bank (SRB) & 0.081 & 0.040 \\
Excavation under bank (EUB) & 0.008 & 0.262 \\
River bed (RB) & 0.067 & 0.100 \\
Areas of rapids, pools or meanders & & 0.058 \\
(ARPM) & 0.085 & 0.001 \\
Aquatic vegetation (AV) & 0.123 & 1.582 \\
Detritus (D) & 5.405 & 6.987 \\
Eigenvalue & 5.404 & \\
Broken-stick & * Variables that most contributed to the formation of axis 1 ( $\geq 0.13)$.
\end{tabular}
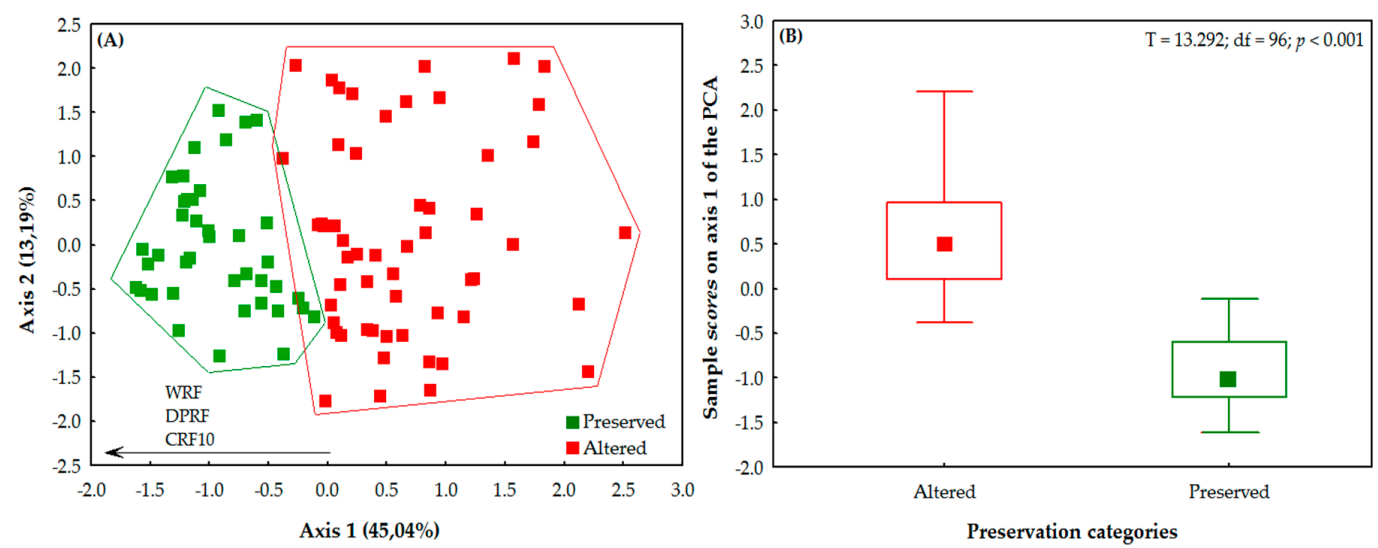

Figure 2. (A) Ordination of environmental variables (values of 12 items of the habitat integrity index (HII)); (B) relation between the scores of the samples on axis 1 of the ordination (PCA) and conservation (preserved and altered) of the streams surveyed in two regions of Brazilian Amazonia, in the state of Pará. $(\mathrm{WRF}=$ width of the riparian forest; DPRF = degree of preservation of the riparian forest; $\mathrm{CRF} 10=$ condition of the riparian forest within a radius of $10 \mathrm{~m}$ ).

\subsection{Effects of Environment and Space on Odonata Communities}

Considering all the environments, $22 \%$ of the variance in the composition of the Odonata communities was explained exclusively by environmental factors (fraction [a]), with no effect of spatial factors (fraction [b]) (Figure 3). Considering only the preserved environments, $23 \%$ of the variance was attributed exclusively to environmental factors (fraction [a]), while the effect of spatial factors (fraction [b]) was, once again, not significant (Figure 3). Considering only the altered environments, $26 \%$ of 
the variance was explained exclusively by environmental factors (fraction [a]) and $1 \%$ was explained solely by spatial factors, i.e., fraction [b] (Figure 3).

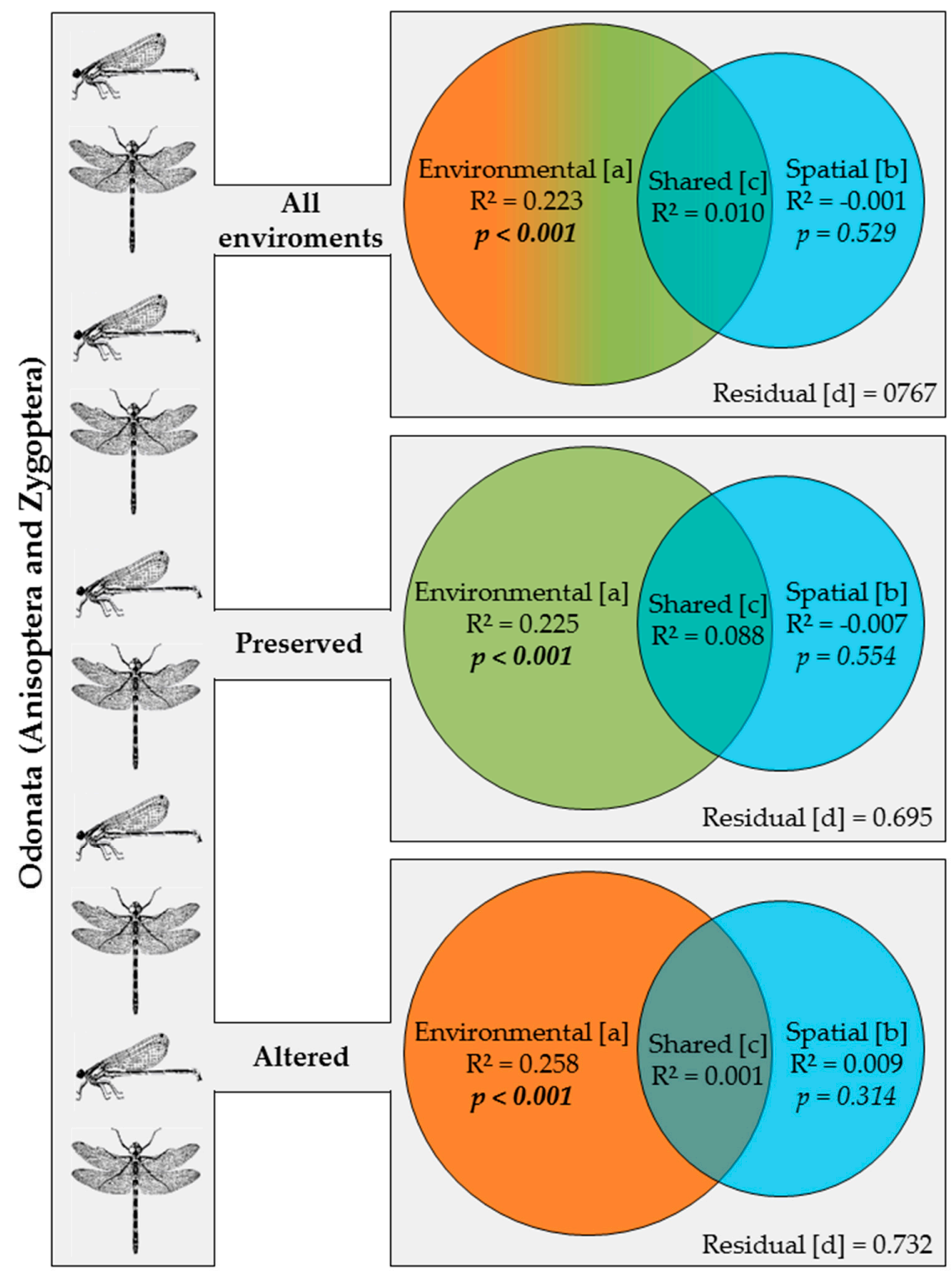

Figure 3. Partition of the variation using the matrix of abundance of the species of Odonata (Anisoptera and Zygoptera) sampled in: all environments; only preserved streams; and only altered streams in two regions of Brazilian Amazonia in the state of Pará. Bold values are significant at the $p<0.05$ level.

In all types of environment, $15 \%$ of the variance in the composition of the Anisoptera community was explained solely by environmental factors (fraction [a]), whereas spatial factors (fraction [b]) did not explain any of the variation found in this community (Figure 4). When the preserved environments are considered separately, none of the variance in species composition is explained by environmental or spatial factors, but in the altered environments, approximately $22 \%$ of the variance in the composition of the Anisoptera community was explained by environmental factors (fraction [a]), but none was accounted for by the spatial fraction (Figure 4). 


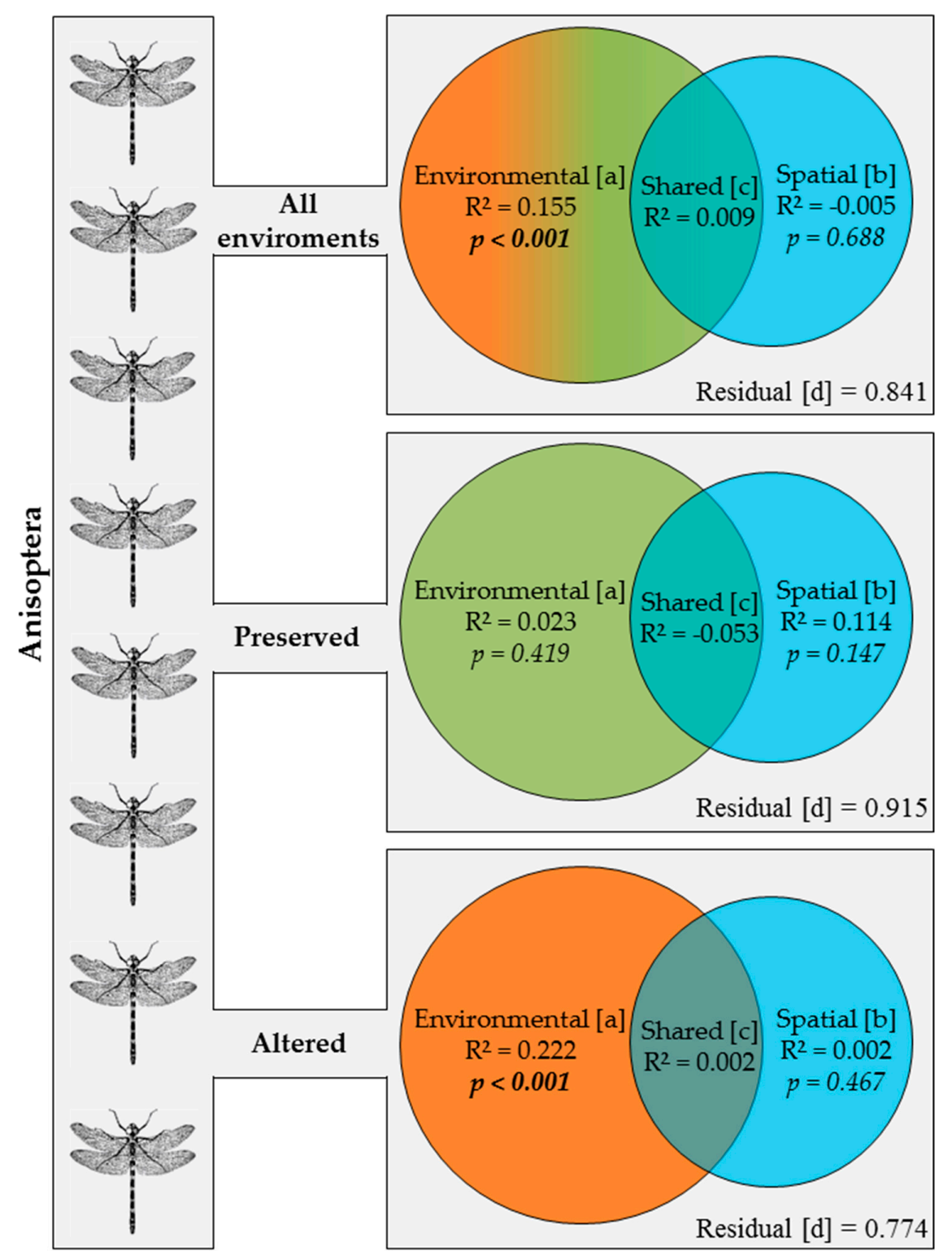

Figure 4. Partition of the variation using the matrix of abundance of the species of Anisoptera sampled in: all environments; only preserved streams; and only altered streams in two regions of Brazilian Amazonia in the state of Pará. Bold values are significant at the $p<0.05$ level.

In the case of Zygoptera, approximately $18 \%$ of the variance in species composition was explained by environmental factors (fraction [a]), whereas none was explained by the spatial fraction [b]. Considering only the preserved environments, $23 \%$ of the variance was explained by environmental factors (fraction [a]), once again with no apparent effect of spatial factors (fraction [b]). In the case of the altered environments, approximately $19 \%$ of the variance in the composition of the Zygoptera community was explained by environmental factors and, once again, none by spatial factors (Figure 5). 


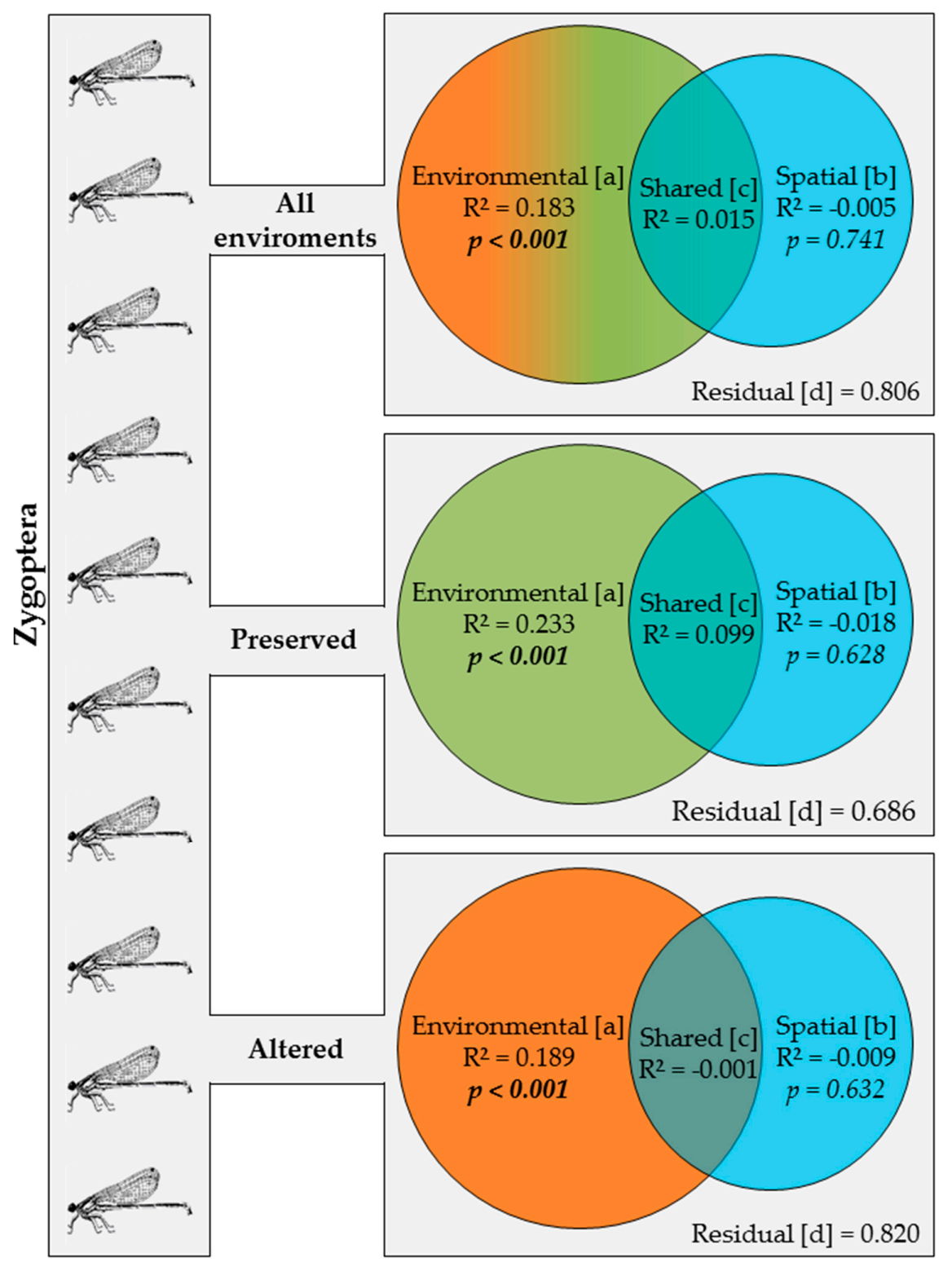

Figure 5. Partition of the variation using the matrix of abundance of the species of Zygoptera sampled in: all environments; only preserved streams; and only altered streams in two regions of Brazilian Amazonia in the state of Pará. Bold values are significant at the $p<0.05$ level.

\section{Discussion}

We have demonstrated that the characteristics of Odonata communities in eastern Amazonia are associated closely with the environmental conditions of the aquatic ecosystems, validating our hypothesis that local communities respond primarily to environmental factors, such as the structure of the riparian vegetation, human impacts, and physical-chemical variables.

From a metacommunity perspective, a number of recent studies have shown that local communities are structured by both environmental factors and spatial processes $[10,87,88]$. However, our results indicate that only environmental factors are important determinants of the variation in the communities (Odonata, Anisoptera, and Zygoptera) in small streams of eastern Amazon.

The structuring of local communities of aquatic insects has often been accounted for by the interaction between spatial processes and local environmental factors [44,45,89], although environmental factors are generally considered the most important $[45,90]$. The predominance of local environmental factors indicates that the mechanisms predicted by niche theory are more important than 
those predicted by neutral theory to explain the structuring of the aquatic insect communities of the small streams of eastern Amazon. While some studies have shown that landscape-level factors, such as the geology, area, and other geographic parameters (latitude, distance between sites), are at least as important as environmental factors, such as the physical-chemical characteristics of the water [91,92], the present study indicated that these variables have a reduced power of explanation. Given this, the species-sorting predictive model of distribution of the local Odonata communities may be determined by the heterogeneity of the environment, acting as a filter of the distribution of species according to the adequacy of habitats, according to the availability of the resources required by the different species. In this context, dispersal is an essential determinant of local species composition, given that the species will become established wherever adequate environmental conditions are found [10].

Many metacommunity studies have concluded that a major portion of the variability remains unaccounted for [44,93-95]. Streams are highly dynamic ecosystems, with considerable stochastic variation [96], and as we did not consider biotic interactions, a large percentage of the unexplained variability was in fact expected. A large part of this variance may be related to other factors, such as competition and sexual selection, as well as environmental variables not measured here or spatial structures that were overlooked due to their complexity [97].

None of the data sets produced by the present study explained more than $26 \%$ of the variability in the composition of the communities (Odonata or Zygoptera and Anisoptera separately) in both types of environment (preserved and altered). This percentage is higher than that recorded by Costa et al. [45] in the ephemeropteran communities in streams in São Paulo, Brazil (17\%), or those found in bacteria (11\%), phytoplankton (7\%), and fish (6\%) in streams in Quebec, Canada [98]. Schulz et al. [95] also recorded a percentage of only $14 \%$ in phytotelmata in the Atlantic Forest of Brazil. However, Mendes et al. [23] recorded a very similar value (29\%) for the influence of environmental factors on the structure of the community of zygopteran larvae in streams of the Brazilian Cerrado. Similar results were also obtained by Heino and Mykrä [43], Costa et al. [45], and Shimano et al. [44], who all showed that the majority of the variability in the composition of ephemeropteran communities was determined by local environmental factors, demonstrating their importance in the structuring of communities of aquatic insects. In streams in central Europe, Feld and Hering [99] observed that $22 \%$ of the variation in the communities of benthonic macroinvertebrates was explained by environmental variables.

Many Odonata species are stenotopic, and thus highly dependent on local conditions [100]. In addition, their dispersal mode and mechanisms have a major impact on the organization of the Odonata metacommunities [101]. Given this, the fact that environmental factors have a greater effect on the structure of zygopteran communities, rather than those of anisopterans, may be related to the reduced dispersal capacity of these smaller-bodied Odonata, which are thus more dependent on local conditions (e.g., physical and chemical parameters of the water (conductivity), channel structure, and plant cover), causing them to focus on a specific resource in the environment, in other words, habitat specialists [102]. One good example of a habitat specialist can be found in the genus Chalcopteryx-the females of this taxon require a specific type of habitat in which to lay their eggs, and are thus found only in preserved environments [103]. A number of other studies of Odonata communities have also found associations between some species and given type of habitat [18,104,105]. In streams in Greece, local environmental variables also played a more important role in the variation in the heteropteran community than geographic dispersal, which was also attributed to the reduced dispersal capacity of this group [106].

Zygopteran species are sensitive to environmental variation due to the restrictions of their ecophysiological requirements [4]. In many cases, the amount of forest cover, especially that located within a radius of $400 \mathrm{~m}$ of the body of water, will have a negative effect (when absent) on the occurrence of species with adults of small size, such as members of the genera Telebasis and Oxyagrivern [107]. As thermal conformers, these species have a high degree of thermal conductance associated with their body size, and body temperature will vary according to the amount of sunlight found in the environment $[23,108]$. In tropical environments, most zygopteran species are associated with shady 
areas, given their high surface to volume ratio of their bodies, which makes them vulnerable to overheating and dehydration under constant exposure to sunlight $[4,109]$. In this context, areas with more open vegetation may represent barriers to the effective dispersal of zygopterans $[27,47,109]$.

Even though anisopterans are more tolerant of different environmental conditions [102], environmental variables still have a fundamental influence on community structure when considering all the environments surveyed or only the altered ones. In preserved environments, however, neither environmental nor spatial effects were observed in the composition of the anisopteran community. Larger individuals, which are typical of this suborder, tend to have more efficient homeostatic mechanisms and greater mobility, which allows them to be more tolerant of different environmental conditions and to range over greater distances [102]. Changes in the landscape may be contributing to an increase in the number of more opportunistic anisopterans (e.g., Diastatops), reducing the effects of both environmental and spatial components on the structuring of this suborder.

Good dispersers, like many anisopterans, should not be limited in any major way by dispersal effects, and when significant spatial structuring of community composition is found, it will usually be related to mass effects [110]. In general, a closer relationship will be found between the dissimilarity of communities and geographic distance over a greater spatial scale [111]. Reduced spatial effects may mean that even areas more than 500 kilometers apart-as in the present study—are not sufficiently distant from one another for the detection of the effects of limitations on dispersal [112,113]. In Finland, Astorga et al. [114] found that freshwater organisms are controlled more by environmental factors than by dispersal, even at distances of up to $1100 \mathrm{~km}$.

\section{Conclusions}

As the two Odonata suborders responded in distinct ways to the two factors (environmental and spatial), the independent analysis of each suborder would probably be an effective measure for the improvement of biomonitoring studies. We suggest that studies of this types would have a greater explanatory potential with the addition of other variables related to biotic interactions (e.g., competition), as well as a finer scale of environmental variation. In this context, further studies will be necessary to determine how the Odonata fauna of the streams of the Amazon region behave from this viewpoint.

Given the current biodiversity crisis, the enormous biological diversity found in aquatic ecosystems, and the social and economic value of the preservation of the quality of aquatic resources, it is increasingly important to develop reliable methods for the measurement, monitoring, and eventual mediation of environmental impacts. The Odonata can potentially provide important insights into the conditions of aquatic ecosystems, although these organisms have been widely overlooked.

Author Contributions: Conceptualization, J.M.B.O.-J. and L.J.; Methodology, J.M.B.O.-J. and L.J.; Formal Analysis, J.M.B.O.-J. and L.J.; Data Curation, J.M.B.O.-J.; Writing-Original Draft Preparation, J.M.B.O.-J. and L.J.; and Writing-Review and Editing, J.M.B.O.-J. and L.J.

Funding: This work was supported by the Brazilian National Science and Technology Council (CNPq) for the doctoral stipend and the Graduate Program in Zoology at UFPA/Goeldi Museum, as well as the CNPq Amazonian Biodiversity and Land Use project (grant number CNPq 574008/2008-0), the Brazilian Agricultural Research Company-EMBRAPA (grant number SEG: 02.08.06.005.00), the Darwin Initiative, United Kingdom (17-023), the Nature Conservancy and Natural Environment Research Council (NERC) (grant number NE/F01614X/1 and NE/G000816/1) for institutional and academic support. LJ also thanks CNPq for a research productivity grant (grant number 307597/2016-4). We thank PROPESP/UFPA for the financial support through Edital 01/2019 (Programa de Apoio à Publicação Qualificada-PAPQ).

Acknowledgments: We would also like to thank the Nelson S. Pinto for assistance with the identification of the anisopteran specimens, and the specialist Frederico Lencioni for the confirmation and identification of the zygopterans, Luciano Montag, Dra. Helena S.R. Cabette, Jorge L. Nessimian and Dra. Neusa Hamada for their valuable contributions to previous versions of this manuscript, and the Paulo Santos Brazil for drawing the map.

Conflicts of Interest: The authors declare no conflict of interest. The funding sponsors had no role in the design of the study; in the collection, analysis, or interpretation of data; in the writing of the manuscript, and in the decision to publish the results. 


\section{References}

1. Loreau, M. Linking biodiversity and ecosystems: Towards a unifying ecological theory. Philos. Trans. R. Soc. Lond. B Biol. Sci. 2010, 365, 49-60. [CrossRef] [PubMed]

2. Márquez, J.C.; Kolasa, J. Local and Regional Processes in Community Assembly. PLoS ONE 2013, 8, e54580. [CrossRef]

3. Pianka, E. Evolutionary Ecology; Harper Collins College Publishers: New York, NY, USA, 1994; p. 484.

4. Juen, L.; De Marco, P. Odonate biodiversity in terra-firme forest streamlets in Central Amazonia: On the relative effects of neutral and niche drivers at small geographical extents. Insect. Conserv. Diver. 2011, 4, 265-274. [CrossRef]

5. Hutchinson, G.E. Concluding remarks. Cold Spring Harb. Symp. Quant. Biol. 1957, 22, 415-427. [CrossRef]

6. Hubbell, S.P. A Unified Neutral Theory of Biodiversity and Biogeography; Princeton University Press: Princeton, NJ, USA, 2001.

7. Hubbell, S.P. Neutral theory in community ecology and the hypothesis of functional equivalence. Funct. Ecol. 2005, 19, 166-172. [CrossRef]

8. Cassemiro, F.A.S.; Padial, A.A. Teoria neutra da biodiversidade e biogeografia: Aspectos teóricos, impactos na literatura e perspectivas. Oecologia Bras. 2008, 12, 706-719. [CrossRef]

9. Chesson, P. Mechanisms of maintenance of species diversity. Annu. Rev. Ecol. Syst. 2000, 31, $343-366$. [CrossRef]

10. Leibold, M.A.; Holyoak, M.; Mouquet, N.; Amarasekare, P.J.; Chase, M.; Hoopes, M.F. The metacommunity concept: A framework for multi-scale community ecology. Ecol. Lett. 2004, 7, 601-613. [CrossRef]

11. Reed, K.E.; Bidner, L.R. Primate communities: Past, present and possible future. Yearb. Phys. Anthropol. 2004, 47, 2-39. [CrossRef] [PubMed]

12. Foote, A.L.; Hornung, C.L.R. Odonates as biological indicators of grazing effects on Canadian prairie wetlands. Ecol. Entomol. 2005, 30, 273-283. [CrossRef]

13. Calvão, L.B.; Vital, M.V.C.; Juen, L.; Lima Filho, G.F.; Oliveira-Junior, J.M.B.; Pinto, N.S.; De Marco, P. Thermoregulation and microhabitat choice in Erythrodiplax latimaculata Ris males (Anisoptera: Libellulidae. Odonatologica 2013, 42, 97-108.

14. Monteiro-Júnior, C.S.; Couceiro, S.R.M.; Hamada, N.; Juen, L. Effect of vegetation removal for road building on richness and composition of Odonata communities in Amazonia, Brazil. Int. J. Odonatol. 2013, 16, 135-144. [CrossRef]

15. Dolný, A.; Bárta, D.; Lhota, S.; Rusdianto; Drozd, P. Dragonflies (Odonata) in the Bornean rain forest as indicators of changes in biodiversity resulting from forest modification and destruction. Trop. Zool. 2011, 24, 63-86.

16. Tiple, A.D.; Paunikae, S.; Talmale, S.S. Dragonflies and Damselflies (Odonata: Insecta) of Tropical Forest research Institute, Jabalpur, Madhya Padesh, Central India. J. Threat. Taxa 2012, 4, 2529-2533. [CrossRef]

17. Simaika, J.P.; Samways, M.J. Using dragonflies to monitor and prioritize lotic systems: A South African perspective. Orgs. Diver. Evol. 2012, 12, 251-259. [CrossRef]

18. Lee, D.; Lee, D.; Bae, M.; Hwang, S.; Noh, S.; Moon, J.; Park, Y. Distribution Patterns of Odonate Assemblages in Relation to Environmental Variables in Streams of South Korea. Insects 2018, 9, 152. [CrossRef] [PubMed]

19. McCauley, S.J. The role of local and regional processes in structuring larval dragonfly distributions across habitat gradients. Oikos 2007, 116, 121-133. Available online: https://www.jstor.org/stable/40234985 (accessed on 17 April 2014). [CrossRef]

20. McCauley, S.J.; Davis, C.J.; Relyea, R.A.; Yurewicz, K.L.; Skelly, D.K.; Werner, E.E. Metacommunity patterns in larval odonates. Oecologia 2008, 158, 329-342. [CrossRef]

21. Brasil, L.S.; Oliveira-Junior, J.M.B.; Calvão, L.B.; Carvalho, F.G.; Monteiro-Júnior, C.S.; Dias-Silva, K.; Juen, L. Spatial, biogeographic and environmental predictors of diversity in Amazonian Zygoptera. Insect Conserv. Divers. 2018, 11, 174-184. [CrossRef]

22. Alves-Martins, F.; Brasil, L.S.; Juen, L.; De Marco, P.; Stropp, J.; Hortal, J. Metacommunity patterns of Amazonian Odonata: The role of environmental gradients and major rivers. PeerJ 2019, 7, e6472. [CrossRef]

23. Mendes, T.P.; Cabette, H.S.R.; Juen, L. Setting boundaries: Environmental and spatial effects on Odonata larvae distribution (Insecta). An. Acad. Bras. Cienc. 2015, 87, 239-248. [CrossRef] [PubMed] 
24. Felipe, T.R.A.; Súarez, Y.R. Caracterização e influência dos fatores ambientais nas assembleias de peixes de riachos em duas microbacias urbanas, Alto Rio Paraná. Biota Neotrop. 2012, 10, 143-151. [CrossRef]

25. Callisto, M.; Moretti, M.; Goulart, M. Macroinvertebrados bentônicos como ferramenta para avaliar a saúde de riachos. Rev. Bras. Recur. Hídricos 2001, 6, 71-82. [CrossRef]

26. Dodds, W.K. Freshwater Ecology: Concepts and Environmental Applications; Academic Press: Cambridge, UK, 2002; p. 569.

27. Carvalho, F.G.; Pinto, N.S.; Oliveira-Júnior, J.M.B.; Juen, L. Effects of marginal vegetation removal on Odonata communities. Acta Limnol. Bras. 2013, 25, 10-18. [CrossRef]

28. Juen, L.; Oliveira-Junior, J.M.B.; Shimano, Y.; Mendes, T.P.; Cabette, H.S.R. Composição e riqueza de Odonata (Insecta) em riachos com diferentes níveis de conservação em um ecótone Cerrado-Floresta Amazônica. Acta Amaz. 2014, 44, 175-184. [CrossRef]

29. Monteiro-Júnior, C.S.; Juen, L.; Hamada, N. Effects of urbanization on stream habitats and associated adult dragonfly and damselfly communities in central Brazilian Amazonia. Landsc. Urban. Plan. 2014, 127, $28-40$. [CrossRef]

30. Monteiro-Júnior, C.S.; Juen, L.; Hamada, N. Analysis of urban impacts on aquatic habitats in the central Amazon basin: Adult odonates as bioindicators of environmental quality. Ecol. Indic. 2015, 48, 303-311. [CrossRef]

31. Oliveira-Junior, J.M.B.; Shimano, Y.; Gardner, T.A.; Hughes, R.M.; De Marco, P.; Juen, L. Neotropical dragonflies (Insecta: Odonata) as indicators of ecological condition of small streams in the eastern Amazon. Austral. Ecol. 2015, 40, 733-744. [CrossRef]

32. Oliveira-Junior, J.M.B.; De Marco, P.; Dias-Silva, K.; Leitão, R.P.; Leal, C.G.; Pompeu, P.S.; Gardner, T.A.; Hughes, R.M.; Juen, L. Effects of human disturbance and riparian conditions on Odonata (Insecta) assemb-Lages in eastern Amazon basin streams. Limnologica 2017, 66, 31-39. [CrossRef]

33. Oliveira-Junior, J.M.B.; Juen, L. The Zygoptera/Anisoptera Ratio (Insecta: Odonata): A New Tool for Habitat Alterations Assessment in Amazonian Streams. Neotrop. Entomol. 2019, 48, 552-560. [CrossRef] [PubMed]

34. Rios, S.L.; Bailey, R.C. Relationship between riparian vegetation and stream benthic communities at three spatial scales. Hydrobiologia 2006, 553, 153-160. [CrossRef]

35. Dumont, H.J.; Vierstraete, A.; Vanfleteren, J.R. A molecular phylogeny of the Odonata (Insecta). Syst. Entomol. 2010, 35, 6-18. [CrossRef]

36. May, M.L. Odonata: Who They Are and What They Have Done for Us Lately: Classification and Ecosystem Services of Dragonflies. Insects 2019, 10, 62. [CrossRef] [PubMed]

37. Stoks, R.; Córdoba-Aguilar, A. Evolutionary ecology of Odonata: A complex life cycle perspective. Annu. Rev. Entomol. 2012, 57, 249-265. [CrossRef] [PubMed]

38. Corbet, P.S. Dragonflies: Behavior and Ecology of Odonata; Comstock Publ. Assoc.: Ithaca, NY, USA, 1999; p. 829.

39. Oertli, B. The use of dragonflies in the assessment and monitoring of aquatic habitats. In Model. Organisms for Ecological and Evolutionary Research; Cordoba-Aguilar, A., Ed.; Oxford University Press: Oxford, UK, 2008; pp. 79-95.

40. Butler, R.G.; de Maynadier, P.G. The significance of littoral and shoreline habitat integrity to the conservation of lacustrine damselflies (Odonata). J. Insect Conserv. 2008, 12, 23-36. [CrossRef]

41. Miguel, T.B.; Oliveira-Junior, J.M.B.; Ligeiro, R.; Juen, L. Odonata (Insecta) as a tool for the biomonitoring of environmental quality. Ecol. Indic. 2017, 81, 555-566. [CrossRef]

42. Gardner, T.A.; Ferreira, J.; Barlow, J.; Lees, A.C.; Parry, L.; Vieira, I.C.G.; Berenguer, E.; Abramovay, R.; Aleixo, A.; Andretti, C.; et al. A social and ecological assessment of tropical land-uses at multiple scales: The Sustainable Amazon Network. Philos. Trans. R. Soci. B 2013, 368, 20120166. [CrossRef] [PubMed]

43. Heino, J.; Mykrä, H. Control of stream insect assemblages: Roles of spatial configuration and local environmental factors. Ecol. Entomol. 2008, 33, 614-622. [CrossRef]

44. Shimano, Y.; Juen, L.; Salles, F.F.; Nogueira, D.S.; Cabette, H.S.R. Environmental and spatial processes determining Ephemeroptera (Insecta) structures in tropical streams. Ann. Limnol.-Int. J. Lim. 2013, 49, 31-41. [CrossRef]

45. Costa, L.S.M.; Zanini Branco, C.C.; Bispo, P.C. O Papel dos Fatores Ambientais e Espaciais Sobre a Fauna de Ephemeroptera (Insecta) em Riachos de Mata Atlântica. EntomoBrasilis 2014, 7, 86-92. [CrossRef] 
46. De Marco, P.; Batista, J.D.; Cabette, H.S.R. Community Assembly of Adult Odonates in Tropical Streams: An Ecophysiological Hypothesis. PLoS ONE 2015, 10, e0123023. [CrossRef] [PubMed]

47. Dutra, S.; De Marco, P. Bionomic differences in odonates and their influence on the efficiency of indicator species of environmental quality. Ecol. Indic. 2015, 49, 132-142. [CrossRef]

48. Watrin, O.S.; Rocha, A.M.A. Levantamento da Vegetação Natural e do Uso da Terra no Município de Paragominas (PA) Utilizando Imagens TM/Landsat; EMBRAPA/CPATU. (EMBRAPA/CPATU); Boletim de Pesquisa: Belém, Brazil, 1992; p. 40.

49. Nepstad, D.C.; Moutinho, P.R.S.; Dias-Filho, M.B.; Davidson, E.; Cardinot, G.; Markewitz, D.; Figueiredo, R.; Vianna, N.; Lefebvre, P.; Ray, D.; et al. The effects of rainfall exclusion on canopy processes and biogeochemistry of an Amazon forest. J. Geophys. Res. 2002, 107, 80-85. [CrossRef]

50. Veloso, H.P.; Rangel Filho, A.L.R.; Lima, J.C.A. Classificação Da Vegetação Brasileira Adaptada a Um Sistema Universal; IBGE: Rio de Janeiro, Brazil, 1991; p. 123.

51. Berenguer, E.; Ferreira, J.; Gardner, T.A.; Aragão, L.E.O.C.; Camargo, P.B.; Cerri, C.E.; Durigan, M.; Oliveira Junior, R.C.; Vieira, I.C.G.; Barlow, J. A large-scale field assessment of carbon stocks in human-modified tropical forests. Glob. Chang. Biol. 2014, 20, 3713-3726. [CrossRef] [PubMed]

52. Moura, N.G.M.; Lees, A.C.L.; Andretti, C.; Davis, B.; Solar, R.; Aleixo, A.; Barlow, J.; Ferreira, J.; Gardner, T.A. Avian biodiversity in multiple-use landscapes of the Brazilian Amazon. Biol. Conserv. 2013, 167, 339-348. [CrossRef]

53. Putz, F.E.; Redford, H.K. The importance of defining 'Forest': Tropical forest degradation, deforestation, long-term phase shifts, and further transitions. Biotropica 2010, 42, 10-20. [CrossRef]

54. May, M.L. Thermoregulation in adaptation to temperature in dragonflies (Odonata: Anisoptera). Ecol. Monogr. 1976, 46, 1-32. [CrossRef]

55. May, M.L. Thermal adaptations of dragonflies, revisited. Adv. Odonatol. 1991, 5, 71-88.

56. Fulan, J.A.; Henry, R. Temporal distribution of immature Odonata (Insecta) on Eichhornia azurea (Kunth) stands in the Camargo Lake, Paranapanema River, São Paulo. Rev. Bras. Entomol. 2007, 51, $224-227$. [CrossRef]

57. Baptista, D.F.; Dorvillé, L.F.M.; Buss, D.F.; Nessiamian, J.L. Spatial and temporal organization of aquatic insects assemblages in the longitudinal gradient of a tropical river. Rev. Bras. Biol. 2001, 61, 295-304. [CrossRef] [PubMed]

58. Heino, J. Taxonomic surrogacy; numerical resolution and responses of stream macroinvertebrate communities to ecological gradients: Are the inferences transferable among regions? Ecol. Indic. 2014, 36, 186-194. [CrossRef]

59. Kaufmann, P.R.; Levine, P.; Robison, G.E.; Seeliger, C.; Peck, D.V. Quantifying Physical Habitat in Wadeable Streams; EPA/620/R-99/003; U.S. Environmental Protection Agency: Washington, DC, USA, 1999; p. 149.

60. Peck, D.V.; Herlihy, A.T.; Hill, B.H.; Hughes, R.M.; Kaufmann, P.R.; Klemm, D.; Lazorchak, J.M.; McCormick, F.H.; Peterson, S.A.; Ringold, P.L.; et al. Environmental Monitoring and Assessment Program-Surface Waters Western Pilot Study: Field Operations Manual for Wadeable Streams; EPA/620/R-06/003; U.S. Environmental Protection Agency: Washington, DC, USA, 2006.

61. De Marco, P.; Resende, D.C. Activity patterns and thermoregulation in a tropical dragonfly assemblage. Odonatologica 2002, 31, 129-138. Available online: http://natuurtijdschriften.nl/record/592390 (accessed on 10 March 2014).

62. Ferreira-Peruquetti, P.; De Marco, P. Efeito da alteração ambiental sobre comunidades de odonata em riachos de Mata Atlântica de Minas Gerais, Brasil. Rev. Bras. Zool. 2002, 19, 32-37. [CrossRef]

63. Lencioni, F.A.A. The Damselflies of Brazil: An Illustrated Guide-Coenagrionidae; All Print Editora: São Paulo, Brazil, 2006; p. 419.

64. Borror, D.J. A key to the New World genera of Libellulidae (Odonata). Ann. Entomol. Soc. Am. 1945, 38, 168-194. [CrossRef]

65. Belle, J. A synopsis of the species of Phyllocycla Calvert with description of four new taxa and a key to the genera of the neotropical Gomphidae (Odonata, Gomphidae). Tijdschr. Voor Entomol. 1988, 131, 73-102.

66. Belle, J. Higher classification of the South-American Gomphidae (Odonata). Zool. Meded. 1996, 70, $298-324$. Available online: https://www.repository.naturalis.nl/document/149750 (accessed on 17 April 2014).

67. Garrison, R.W. A synopsis of the genus Hetaerina with descriptions of four new species (Odonata: Calopterigidae). Trans. Amer. Entomol. Soci. 1990, 116, 175-259. [CrossRef] 
68. Lencioni, F.A.A. The Damselflies of Brazil: An Illustrated Guide—The Non Coenagrionidae Families; All Print Editora: São Paulo, Brazil, 2005; p. 332.

69. Garrison, R.W.; Von Ellenrieder, N.; Louton, J.A. Dragonfly Genera of the New Word: An illustrated and Annotated Key to the Anisoptera; The Johns Hopkins University Press: Baltimore, MA, USA, 2006; p. 368.

70. Garrison, R.W.; Von Ellenrieder, N.; Louton, J.A. Damselfly genera of the New World. In Baltimore, An Illustrated and Annotated Key to the Zygoptera; The Johns Hopkins University Press: Baltimore, MA, USA, 2010; p. 490.

71. Nessimian, J.L.; Venticinque, E.; Zuanon, J.; De Marco, P.; Gordo, M.; Fidelis, L.; Batista, J.D.; Juen, L. Land use, habitat integrity, and aquatic insect assemblages in Central Amazonian streams. Hydrobiologia 2008, 614, 117-131. [CrossRef]

72. Pereira, L.R.; Cabette, H.S.R.; Juen, L. Trichoptera as bioindicators of habitat integrity in the Pindaíba river basin, Mato Grosso (Central Brazil). Ann. Limnol.-Int. J. Lim. 2012, 48, 295-302. [CrossRef]

73. Giehl, N.F.S.; Dias-Silva, K.; Juen, L.; Batista, J.D.; Cabette, H.S.R. Taxonomic and Numerical Resolutions of Nepomorpha (Insecta: Heteroptera) in Cerrado Streams. PLoS ONE 2014, 9, e103623. [CrossRef]

74. Borcard, D.; Legendre, P. All-scale spatial analysis of ecological data by means of principal coordinates of neighbour matrices. Ecol. Model. 2002, 153, 51-68. [CrossRef]

75. Diniz-Filho, J.A.F.; Bini, L.M. Modelling geographical patterns in species richness using eigenvector-based spatial filters. Glob. Ecol. Biogeogr. 2005, 14, 177-185. [CrossRef]

76. Rangel, T.F.L.V.B.; Diniz-Filho, J.A.F.; Bini, L.M. Towards an integrated computational tool for spatial analysis in macroecology and biogeography. Glob. Ecol. Biogeogr. 2006, 15, 321-327. [CrossRef]

77. Ferreira, W.R.; Ligeiro, R.; Macedo, D.; Hughes, R.M.; Kaufmann, P.R.; Oliveira, L.G.; Callisto, M. Importance of environmental factors for the richness and distribuition of benthic macroinvertebrates in tropical headwater streams. Freshw. Sci. 2014, 33, 860-871. [CrossRef]

78. Jackson, D.A. Stopping rules in principal components analysis: A comparison of heuristical and statistical approaches. Ecology 1993, 74, 2204-2214. [CrossRef]

79. Anderson, M.J. Distance-based tests for homogeneity of multivariate dispersions. Biometrics 2006, 62, $245-253$. [CrossRef]

80. Peres-Neto, P.R.; Legendre, P. Estimating and controlling for spatial structure in the study of ecological communities. Glob. Ecol. Biogeogr. 2010, 19, 174-184. [CrossRef]

81. Legendre, P.; Gallagher, E. Ecologically meaningful transformations for ordination of species data. Oecologia 2001, 129, 271-280. [CrossRef]

82. Peres-Neto, P.R.; Legendre, P.; Dray, S.; Borcard, D. Variation partitioning of species data matrices: Estimation and comparison of fractions. Ecology 2006, 87, 2614-2625. [CrossRef]

83. Borcard, D.; Legendre, P.; Drapeau, P. Partialling out the spatial component of ecological variation. Ecology 1992, 73, 45-55. Available online: http://www.jstor.org/stable/1940179 (accessed on 22 April 2014). [CrossRef]

84. Oksanen, J.; Kindt, R.; Legendre, P.; O’Hara, B. The vegan package. Community Ecol. Package 2007, 10, 631-637. Available online: http://www.R-project.org (accessed on 12 May 2014).

85. Venables, W.N.; Ripley, B.D. Modern Applied Statistics with S, 4th ed.; Springer: New York, NY, USA, 2002; p. 498. [CrossRef]

86. R Development Core Team. Importance of Environmental Factors for the Richness and Distribuition of Benthic Macroinvertebrates in Tropical Headwater Streams; R Foundation for Statistical Computing: Vienna, Austria, 2011; ISBN 3-900051-07-0. Available online: http://www.R-project.org/ (accessed on 12 May 2014).

87. Chase, J.M.; Bentgtsson, J. Increasing spatio-temporal scales: Metacommunity ecology. In Community Ecology: Processes, Models and Applications; Verhoef, H.A., Morin, P.J., Eds.; Oxford University Press: Oxford, UK, 2010; pp. 57-68.

88. Cottenie, K. Integrating environmental and spatial processes in ecological community dynamics. Ecol. Lett. 2005, 8, 1175-1182. [CrossRef] [PubMed]

89. Siqueira, T.; Bini, L.M.; Roque, F.O.; Couceiro, S.R.M.; Trivino-Strixino, S.; Cottenie, K. Common and rare species respond to similar niche processes in macroinvertebrate metacommunities. Ecography 2012, 35, 183-192. [CrossRef]

90. Landeiro, V.L.; Bini, L.M.; Melo, A.S.; Pes, A.M.O.; Magnusson, W.E. The roles of dispersal limitation and environmental conditions in controlling caddisfly (Trichoptera) assemblages. Freshw. Biol. 2012, 57, 1554-1564. [CrossRef] 
91. Corkum, L.D. Patterns of benthic invertebrate assemblages in rivers of north-western North America. Freshw. Biol. 1989, 21, 191-205. [CrossRef]

92. Lammert, M.; Allan, J.D. Assessing biotic integrity of streams: Effects of scale in measuring the influence of land use/ cover and habitat structure on fish and macroinvertebrates. Environ. Manag. 1999, 23, 257-270. [CrossRef]

93. Göthe, E.; Angeler, D.G.; Sandin, L. Metacommunity structure in a small boreal stream network. J. Anim. Ecol. 2013, 82, 449-458. [CrossRef]

94. Nabout, J.C.; Siqueira, T.; Bini, L.M.; Nogueira, I.S. No evidence for environmental and spatial processes in structuring phytoplankton communities. Acta Oecol. 2009, 35, 720-726. [CrossRef]

95. Schulz, G.; Siqueira, T.; Stefan, G.; Roque, F.O. Passive and active dispersers respond similarly to environmental and spatial processes: An example from metacommunity dynamics of tree hole invertebrates. Fundam. Appl. Limnol. 2012, 181, 315-326. [CrossRef]

96. Death, R.G. Predicting invertebrate diversity from disturbance regimes in Forest streams. Oikos 2002, 97, 18-30. [CrossRef]

97. Borcard, D.; Gillet, F.; Legendre, P. Numerical Ecology with R; Springer: New York, NY, USA, 2011; p. 302.

98. Beisner, B.E.; Peres-Neto, P.R.; Lindstro, E.S.; Barnett, A.; Longhi, M.L. The role of environmental and spatial processes in structuring lake communities from bacteria to fish. Ecology 2006, 87, 2985-2991. [CrossRef]

99. Feld, C.K.; Hering, D. Community structure or function: Effects of environmental stress on benthic macroinvertebrates at different spatial scales. Freshw. Biol. 2007, 52, 1380-1399. [CrossRef]

100. McPeek, M.A. Ecological factors limiting the distributions and abundances of Odonata. Dragonflies \& Damselflies. In Model Organisms for Ecological and Evolutionary Research; Córdoba-Aguilar, A., Ed.; Oxford University Press: Oxford, UK, 2008; pp. 51-62.

101. Landeiro, V.L.; Magnusson, W.E.; Melo, A.S.; Espírito-Santo, H.M.V.; Bini, L.M. Spatial eigenfunction analyses in stream networks: Do watercourse and overland distances produce different results? Freshw. Biol. 2011, 56, 1184-1192. [CrossRef]

102. Tscharntke, T.; Steffan-Dewenter, I.; Kruess, A.; Thies, C. Contribution of small habitat fragments to conservation of insect communities of grassland-cropland landscapes. Ecol. Appl. 2002, 12, 354-363. [CrossRef]

103. Resende, D.C. Residence advantage in heterospecific territorial disputes of Erythrodiplax Brauer species (Odonata, Libellulidae). Rev. Bras. Entomol. 2010, 54, 110-114. [CrossRef]

104. Clark, T.E.; Samways, M.J. Dragonflies (Odonata) as indicators of biotope quality in the Kruger National Park, South Africa. J. Appl. Ecol. 1996, 33, 1001-1012. [CrossRef]

105. Schindler, M.; Fesl, C.; Chovanec, A. Dragonfly associations (Insect: Odonata) in relation to habitat variables: A multivariate approach. Hydrobiologia 2003, 497, 169-180. [CrossRef]

106. Karouzas, I.; Gritzalis, K.C. Local and regional factors determining aquatic and semi-aquatic bug (Heteroptera) assemblages in rivers and streams of Greece. Hydrobiologia 2006, 573, 199-212. [CrossRef]

107. Pither, J.; Taylor, P.D. An experimental assessment of landscape connectivity. Oikos 1998, 83, 166-174. [CrossRef]

108. Heinrich, B. The Hot-Blooded Insects: Strategies and Mechanism of Thermoregulation; Harvard University Press: Cambridge, MA, USA, 1993; p. 601. [CrossRef]

109. Paulson, D. The importance of forest to Neotropical dragonflies. In Forest and Dragonflies; Cordero Rivera, A., Ed.; Pensoft Publishers: Sofia, Balkans, 2006; pp. 79-101.

110. Heino, J. The importance of metacommunity ecology for environmental assessment research in the freshwater realm. Biol. Rev. 2013, 88, 166-178. [CrossRef]

111. Nekola, J.C.; White, P.S. The distance decay of similarity in biogeography and ecology. J. Biogeogr. 1999, 26, 867-878. [CrossRef]

112. Brow, B.L.; Swan, C.M. Dendritic network structure constrains metacommunity properties in riverine ecosystems. J. Anim. Ecol. 2010, 79, 571-580. [CrossRef] [PubMed]

113. Heino, J.; Grönroos, M.; Soininen, J.; Virtanen, R.; Muotka, T. Context dependency and metacommunity structuring in boreal headwater streams. Oikos 2012, 121, 537-544. [CrossRef]

114. Astorga, A.; Oksanen, J.; Luoto, M.; Soininen, J.; Virtanen, R.; Muotka, T. Distance decay of similarity in freshwater communities: Do macro- and microorganisms follow the same rules? Glob. Ecol. Biogeogr. 2012, 21, 365-375. [CrossRef] 
(C) 2019 by the authors. Licensee MDPI, Basel, Switzerland. This article is an open access article distributed under the terms and conditions of the Creative Commons Attribution (CC BY) license (http://creativecommons.org/licenses/by/4.0/). 